\title{
Carcinogenic potential of hydrotreated petroleum aromatic extracts
}

\author{
SHEILA M A DOAK, R W HEND, A VAN DER WIEL, ${ }^{*}$ AND P F HUNT \\ From Shell Research Ltd, Sittingbourne Research Centre, Sittingbourne, Kent ME9 8AG, UK
}

ABSTRACT Five experimental petroleum extracts were produced from luboil distillates derived from Middle East paraffinic crude by solvent extraction and severe hydrotreatment. The polycyclic aromatic content (PCA) of the extracts was determined by dimethyl sulphoxide extraction and ranged from $3 \cdot 7-9 \cdot 2 \% \mathrm{w} / \mathrm{w}$. The five extracts were evaluated for their potential to induce cutaneous and systemic neoplasia in female mice derived from Carworth Farm No 1 strain (CF1). The test substances were applied undiluted $(0.2 \mathrm{ml}$ per application) to the shorn dorsal skin twice weekly for up to 78 weeks, with 48 mice in each treatment group and 96 in the untreated control group; two further groups, each of 48 mice, were similarly treated either with a non-hydrotreated commercial aromatic extract (PCA content, 19.7\% w/v) or with a low dose of benzo(a)pyrene $(12.5 \mu \mathrm{g} / \mathrm{ml}$ acetone). The mice were housed individually in polypropylene cages in specified pathogen free conditions. The incidence of cutaneous and systemic tumours was determined from histological analysis of haematoxylin and eosin stained tissue sections. The results were correlated with the PCA content of the extracts and compared with those from female mice exposed to a non-hydrotreated commercial aromatic extract. Four of the hydrotreated extracts were carcinogenic for murine skin; the two products with the lower PCA contents were less carcinogenic than the products with the higher PCA contents and all were less carcinogenic than the commercial extract. One extract with the lowest PCA content was noncarcinogenic. Thus refining by severe hydrotreatment was an effective method of reducing the carcinogenic potential of petroleum aromatic extracts. Although other physicochemical properties may influence the biological activity of oil products, the PCA content determined by dimethyl sulphoxide extraction may be a useful indicator of the potential of oil products to induce cutaneous tumours in experimental animals. There was no evidence that the commercial or hydrotreated extracts increased the incidence of systemic neoplasms when applied twice weekly to the dorsal skin.

In 1932 several pure polycyclic aromatic compounds (PCA) were shown to induce malignant tumours in laboratory animals after topical application to the interscapular skin or after subcutaneous injection.' The authors suggested, on the basis of fluorescent properties, that PCA compounds were the carcinogens in such complex mixtures as coal tars, shale oil, and heated petroleum products. With the isolation of 3,4-benzo(a)pyrene from coal $\operatorname{tar}^{2}$ the presence of an identified chemical carcinogen could be associated with the carcinogenic property of an

\footnotetext{
*Formerly of Koninklijke/Shell Laboratorium, Amsterdam, Netherlands.
}

Received 16 July 1984

Accepted 13 August 1984 industrial product. There is now substantial evidence $^{3}$ that the potential of some oils and oil pro- 9 ducts to induce tumours in laboratory animals is due, at least in part, to their content of PCA compounds.

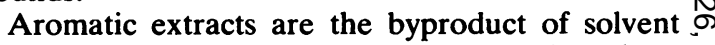
extraction in the refining of petroleum oils. These $N$ extracts have a high PCA content (more than $5 \%$ by $\underset{\mathrm{N}}{ }$ weight) and will contain some carcinogenic 4-6 0 membered condensed ring structures. A research programme was designed to investigate whether aromatic extracts could be developed with acceptable functional properties and low carcinogenic 0 activity. A series of experimental aromatic extracts with reduced PCA content was produced by severe $\mathbb{D}$ hydrotreatment for technical and toxicological 
evaluation. The PCA content of the extracts was determined by dimethyl sulphoxide extraction. ${ }^{4}$

The study, reported here, was carried out to assess the cutaneous and systemic carcinogenic potential of a series of five experimental hydrotreated aromatic extracts. Using female CF1 mice, the incidence of tumours was compared with that from mice exposed to a commercial aromatic extract with a PCA content of $19.7 \% \mathrm{w} / \mathrm{w}$.

\section{Materials and methods}

ANIMALS

Female mice, derived from Carworth Farm No 1 strain (CF1), were used. The animals were bred and maintained under specified pathogen free (SPF) conditions at Sittingbourne Research Centre.

\section{TEST MATERIALS}

A commercial aromatic extract and five experimental hydrotreated aromatic extracts were tested. Four extracts were obtained from luboil distillates and one from residual oil; all were derived from Middle East paraffinic crude and were coded as follows for reference purposes;

$C A E$-Commercial aromatic extract; an untreated light machine oil aromatic luboil extract from furfural extraction of LMO distillate.

HTAE 1-Experimental hydrotreated aromatic extract; a pilot plant hydrotreated medium machine oil aromatic luboil extract, topped at $330^{\circ} \mathrm{C}$ and solvent dewaxed.

HTAE 2-Experimental hydrotreated aromatic extract; a pilot plant hydrotreated MMO aromatic luboil extract, topped at $330^{\circ} \mathrm{C}$ (not dewaxed).

HTAE 3-Experimental hydrotreated aromatic extract; a plant hydrotreated MMO aromatic luboil extract.

HTAE 4-Experimental hydrotreated aromatic extract; a pilot plant hydrotreated MMO aromatic luboil extract, topped at $395^{\circ} \mathrm{C}$ and solvent dewaxed.

HTAE 5-Experimental hydrotreated aromatic extract; a pilot plant hydrotreated residual oil extract, topped at $320^{\circ} \mathrm{C}$ and solvent dewaxed.

The characteristic bulk properties and analytical data on the test aromatic extracts are presented in table 1 .

The extracts were stored in 2.5 litre cans at $21^{\circ} \mathrm{C}$. Samples were decanted into darkened all glass $250 \mathrm{ml}$ bottles for use in the experimental SPF unit as required.

POSITIVE CONTROL COMPOUND

Benzo(a)pyrene (B-a-P) was supplied by KochLight Ltd, Colnbrook, Bucks, UK (batch No 62962; purity $95 \%$ ). The B-a-P solution was prepared immediately before use at a concentration of $12.5 \mu \mathrm{g} / \mathrm{ml}$ in acetone.

EXPERIMENTAL PROCEDURE

The mice, aged 6 weeks when treatment started, were housed singly in polypropylene cages lined with sawdust bedding. The mice were fed a nutritionally adequate rodent diet (LAD 1, supplied by Spratts Patent Ltd, Barking, Essex) and provided with drinking water ad libitum. Throughout the experiment, the animals were kept in one room of an SPF experimental unit, maintained at a temperature of $21^{\circ} \mathrm{C} \pm 2^{\circ} \mathrm{C}$ with a relative humidity of 45 $60 \%$. The light cycle was 12 hours light alternating with 12 hours darkness.

Having regard to their litter origin, the animals were allocated to treatment groups and uniquely identified by ear marking. There were seven treatment groups of 48 mice and a control group of 96 mice.

The hair on the back of each mouse was shorn with fine electric clippers (lubricated with medicinal grade liquid paraffin) before treatment started and thereafter at weekly intervals as required.

The test extracts were applied undiluted to the shorn dorsal skin using glass/stainless steel syringe repettes (supplied by Jencons Ltd, Hemel Hempstead, Hertfordshire). Treatments were carried out twice weekly $(0.2 \mathrm{ml} /$ treatment $)$ for 78 weeks. The control mice were similarly shorn, but received no treatment.

\section{CLINICAL OBSERVATIONS}

Mice were observed daily throughout the study and records were kept of survival time, clinical signs of ill health, and changes in the appearance of the skin, particularly of the treated site. The survival time for each animal was expressed in weeks to the nearest whole week from the beginning of treatment. The size, appearance, and site of all cutaneous and subcutaneous nodular lesions were documented.

\section{PATHOLOGY}

All animals removed from the study through ill health and those surviving to the end of the study were killed by intraperitoneal injection of sodium pentobarbitone. All mice were necropsied and all macroscopic observations were recorded. Tissues were fixed in $10 \%$ neutral formalin and processed for histological examination. Microscopic examination was carried out routinely on haematoxylin and eosin stained sections of skin from the treated site, including all cutaneous nodules, and of the major viscera. Additional stained sections were prepared from all other tissues in which lesions were identified 
Table 1 Characteristic bulk properties and analytical data on aromatic extracts

\begin{tabular}{|c|c|c|c|c|c|c|c|}
\hline Test method & Property & $C A E$ & $H T A E l$ & $H T A E 2$ & HTAE 3 & HTAE 4 & HTAE 5 \\
\hline $\begin{array}{l}\text { ASTM D } 445 \\
\text { ASTM D } 2270 \\
\text { ASTM D } 97 \\
\text { IP 190 } \\
\text { ASTM D } 1500 \\
\text { ASTM D } 1747 \\
\text { 13C NMR } \\
\text { ASTM D } 611 \\
\text { SLC } \\
\text { Microcoulometry } \\
\text { IP } 346 / 80\end{array}$ & $\begin{array}{l}\text { Kinematic viscosity, cSt at } 40^{\circ} \mathrm{C} \\
\text { Viscosity index } 100^{\circ} \mathrm{C} \\
\text { Pour point }\left({ }^{\circ} \mathrm{C}\right) \\
\text { Density at } 20^{\circ} \mathrm{C}(\mathrm{g} / \mathrm{ml}) \\
\text { ASTM colour } \\
\text { Refractive index at } 25^{\circ} \mathrm{C} \\
\text { Aromatic carbon content }\left(\% \mathrm{C}_{\mathrm{A}}\right) \\
\text { Aniline point }\left({ }^{\circ} \mathrm{C}\right) \\
\text { Aromatics content (\% mass) } \\
\text { Sulphur content (\% mass) } \\
\text { PCA extract: } \\
\text { Content (\% m) } \\
\text { Refractive index at } 25^{\circ} \mathrm{C}\end{array}$ & $\begin{array}{l}405 \cdot 6 \\
15 \cdot 21 \\
-67 \\
+12 \\
0 \cdot 9882 \\
\text { D8.0 } \\
1 \cdot 5574 \\
33 \\
41 \cdot 2 \\
81 \cdot 6 \\
3 \cdot 35 \\
19 \cdot 7 \\
1 \cdot 658\end{array}$ & $\begin{array}{c}207 \cdot 1 \\
12 \cdot 46 \\
8 \\
+10 \\
0.9458 \\
\text { D8.0 } \\
1 \cdot 5296 \\
25 \\
62 \cdot 8 \\
72 \cdot 4 \\
0.31\end{array}$ & $\begin{array}{c}197 \cdot 3 \\
12 \cdot 28 \\
13 \\
+24 \\
0.9446^{*} \\
\text { D8.0 } \\
1.5293 \\
26 \\
64.4 \\
71.4 \\
0.31\end{array}$ & $\begin{array}{c}348 \cdot 7 \\
16 \cdot 20 \\
-6 \\
+15 \\
0 \cdot 9461 \\
\text { D8.0 } \\
1 \cdot 5271 \\
23 \\
65 \cdot 9 \\
74 \cdot 0 \\
0 \cdot 27\end{array}$ & $\begin{array}{c}259 \cdot 9 \\
14 \cdot 31 \\
10 \\
+10 \\
0 \cdot 9392 \\
D 8 \cdot 0 \\
1 \cdot 5221 \\
22 \\
70 \cdot 8 \\
68 \cdot 5 \\
0 \cdot 22\end{array}$ & $\begin{array}{l}565 \cdot 5 \\
26 \cdot 07 \\
51 \\
+12 \\
0.9333 \\
\text { D8.0 } \\
1 \cdot 5206 \\
21 \\
82 \cdot 8 \\
74 \cdot 0 \\
0.73\end{array}$ \\
\hline
\end{tabular}

*Extrapolated value.

ASTM = American Society of Testing Materials, Series D. IP = Institute of Petroleum.

References: $13_{\mathrm{C}}$ NMR (PA Couperus, unpublished observations); SLC (A Van der Wiel, BC Ernsting, unpublished); microcoulometrys; IP 346/80.4

at necropsy and from the paired inguinal, brachial, and axillary lymph nodes of animals with cutaneous nodules.

Cutaneous tumours were diagnosed by histological criteria and designated benign or malignant. Some epidermal tumours sloughed spontaneously; although no histological diagnosis of these tumours was possible, they were classified as benign for the purposes of statistical analysis, provided that they had attained a diameter of $2 \mathrm{~mm}$ and had persisted thereafter for at least two weeks.

Assessment of cutaneous irritation was made from the degree of epidermal acanthosis induced by treatment. The epidermal thickness was expressed as the mean number of of nucleated cell layers counted at 10 sites along a sagittal section of skin from the treated site. The mean was designated the irritancy value. The irritancy values so derived were grouped according to treatment and survival. Four periods were evaluated, weeks 1-20, 21-40, 41-60, and 61-78. The number of animals in each period varied, since only those animals dying or killed during each period were evaluated. No animals were specifically detailed for necropsy before the end of the 78 week study to determine irritative effects of treatment.

\section{STATISTICAL ANALYSES}

Percentage survival at the end of the study for each of the treatment groups was tested against the untreated control group using Fisher's exact $2 \times 2$ test.

The number of mice with cutaneous tumours $(>2 \mathrm{~mm})$ of the treated site and with systemic tumours were analysed separately, using the methods described by Peto $e^{2} a^{6}$ which allow for intercurrent mortality. For cutaneous tumours, the time from initial treatment to the development of the first tumour of $2 \mathrm{~mm}$ diameter was noted; using this information the observed and expected numbers of mice with such tumours were determined for each of the seven treated groups. The expected numbers of mice with systemic tumours were calculated taking into account whether each tumour was fatal or incidental. Each tumour was regarded as either fatal, if it was directly or indirectly the cause of death, or incidental.

The hypothesis that the groups had been exposed to a homogeneous risk of tumour development was tested using the $\chi^{2}$ statistic, which is based on the difference between the observed $(O)$ and the expected (E) numbers of mice with tumours. Significantly large values of $\chi^{2}$ imply rejection of this hypothesis, and the ratios of the observed to expected (O:E) indicate the variation in this risk among the groups. For both cutaneous and systemic tumours, analysis was concerned with the seven treated groups and the control group, with increased risk in the treated groups compared with control being of interest; $\chi^{2}$ is distributed as approximately chi-square on seven degrees of freedom.

The probability of avoiding a $2 \mathrm{~mm}$ cutaneous tumour through the duration of the study for the groups was depicted as a life table.

\section{Results}

SURVIVAL

Exposure, by cutaneous application, to the commercial and four of the hydrotreated aromatic extracts significantly reduced the number of survivors to the end of the study compared with that of the untreated controls; of the 48 animals exposed to CAE, HTAE 1, HTAE 2, HTAE 3, and HTAE 4, 0, 2, 0, 18 , and 20 animals survived respectively. By contrast, survival after exposure to HTAE 5 was 35 of 
48, which compares with that of the untreated controls-namely, 68 of 96 . The survival of the positive control group (B-a-P) was slightly lower, 26 of 48 , compared with that of the untreated controls. Tissues from two mice in the latter group are not included in any histological analysis because of a technical error during processing; thus the effective group size of the positive control group was 46 .

An assessment was made of the aetiology of death/terminal illness of 261 decedents by correlating the necropsy and histological findings with clinical signs. The major causes of death are summarised in table 2. Treatment related cutaneous ulceration and cutaneous neoplasia accounted for $59 \%$ of premature deaths in the extract treated groups, with the highest incidences recorded for CAE, HTAE 1, HTAE 2, and HTAE 3 groups. Nine deaths attributable to systemic amyloidosis occurred in groups exposed to four of the hydrotreated aromatic extracts.

The other causes of premature mortality in treated mice were not related to exposure, with similar incidences in both treated and control groups. Systemic neoplasia, mainly of lymphoreticular tissue and lungs, was responsible for 52 deaths. A further 47 deaths were attributable to spontaneous inflammatory disease; most of these were cases of severe nephritis, often associated with systemic hypertension and degenerative vascular lesions. For 22 mice no correlation between clinical signs and histological findings was obtained.

\section{PRIMARY CUTANEOUS IRRITATION}

Primary cutaneous irritation was induced at the treated site after exposure to all the aromatic extracts except HTAE 5; $50 \%$ of mice treated with HTAE 3 and HTAE 4 and nearly all mice exposed to CAE, HTAE 1, and HTAE 2 were affected.
Secondary ulcerative lesions were seen on the neck and shoulders of many treated animals; sometimes the ulceration extended to the forelimbs and flanks. These lesions were self inflicted by scratching in response to irritation induced by treatment of the dorsal skin. Secondary lesions of this type, arising from minor abrasions incurred during normal grooming, were also seen in three untreated controls, three mice exposed to B-a-P, and five to HTAE 5.

The number of nucleated epidermal cell layers was assessed histologically from sections of the dorsal skin of all animals with intact interfollicular epidermis. Table 3 gives the results expressed as the mean number of of epidermal cell layers grouped according to treatment and survival time. The commercial extract and four hydrotreated extracts were irritant to murine skin. There was a two to fourfold increase in the number of epidermal cell layers in these treated mice compared with that in untreated controls. Neither HTAE 5 nor B-a-P treatment induced epidermal hyperplasia.

\section{CUTANEOUS TUMOURS}

Stained sections of all cutaneous nodules seen at necropsy were examined microscopically. Based on histological criteria the following cutaneous tumour types were identified:

Benign epidermal tumour

Papilloma,

Malignant epidermal tumour

Squamous cell carcinoma,

Basal cell carcinoma,

Anaplastic carcinoma,

Malignant dermal tumour

Fibrosarcoma.

Five of the six aromatic extracts (all excepting HTAE 5) were carcinogenic for murine skin. Table 4

Table 2 Aetiology of death or terminal illness of CF1 female mice after repeated topical application to the dorsal skin of $B-a-P$ or one of six petroleum aromatic extracts for up to 78 weeks

\begin{tabular}{|c|c|c|c|c|c|c|c|c|}
\hline & \multicolumn{8}{|c|}{ No of animals } \\
\hline & Untreated & $B-a-P$ & $C A E$ & HTAE 1 & HTAE 2 & HTAE 3 & HTAE 4 & HTAE 5 \\
\hline Initial group size & 96 & 48 & 48 & 48 & 48 & 48 & 48 & 48 \\
\hline No decedents & 28 & $20^{*}$ & 48 & 46 & 48 & 30 & 28 & 13 \\
\hline Cutaneous ulceration & & & 15 & 19 & 21 & 17 & 9 & 1 \\
\hline Cutaneous neoplasia & & 3 & 30 & 6 & 6 & & 2 & \\
\hline $\begin{array}{l}\text { Systemic neoplasia } \\
\text { Inflammatory lesions, }\end{array}$ & 15 & 8 & 1 & 2 & 5 & 6 & 9 & 6 \\
\hline $\begin{array}{l}\text { viscera } \\
\text { Amyloidosis }\end{array}$ & 11 & 8 & 1 & $\begin{array}{r}11 \\
3\end{array}$ & $\begin{array}{l}6 \\
1\end{array}$ & $\begin{array}{l}2 \\
3\end{array}$ & $\begin{array}{l}4 \\
2\end{array}$ & 4 \\
\hline Accident & 1 & & & 1 & & & & \\
\hline Not determined & 1 & 1 & 1 & 4 & 9 & 2 & 2 & 2 \\
\hline Found dead & 5 & 3 & 8 & 3 & 4 & 1 & 1 & 2 \\
\hline Killed owing to illness & 23 & 19 & 40 & 43 & 44 & 29 & 27 & 11 \\
\hline
\end{tabular}

${ }^{*}$ Two mice dying before end of study excluded from analysis (see text). 
Table 3 Mean number of epidermal cell layers in dorsal skin of CF1 female mice after repeated topical application of $B-a-P$ or one of six petroleum aromatic extracts for up to 78 weeks. (No of animals in parentheses)

\begin{tabular}{|c|c|c|c|c|c|c|c|c|}
\hline \multirow{2}{*}{$\begin{array}{l}\text { Period } \\
\text { (weeks) }\end{array}$} & \multicolumn{8}{|c|}{ Mean No of epidermal cell layers } \\
\hline & Untreated & $B-a-P$ & $C A E$ & HTAE 1 & HTAE 2 & HTAE 3 & HTAE 4 & HTAE 5 \\
\hline $\begin{array}{r}0-20 \\
21-40 \\
41-60 \\
61-78\end{array}$ & $\begin{array}{l}1.2(1) \\
1.5(3) \\
1.5(9) \\
1.6(83)\end{array}$ & $\begin{array}{l}1.6(2) \\
1.6(4) \\
1.5(8) \\
1.9(26)\end{array}$ & $\begin{array}{l}4 \cdot 2(2) \\
5 \cdot 5(1) \\
* \\
*\end{array}$ & $\begin{array}{l}4 \cdot 5(1) \\
5 \cdot 4(6) \\
4 \cdot 2(11) \\
4 \cdot 1(2)\end{array}$ & $\begin{array}{l}4 \cdot 1(1) \\
4 \cdot 2(8) \\
4 \cdot 7(16)\end{array}$ & $\begin{array}{l}* \\
2 \cdot 8(1) \\
4 \cdot 3(8) \\
3 \cdot 0(30)\end{array}$ & $\begin{array}{l}* \\
4 \cdot 0(2) \\
3 \cdot 7(10) \\
3 \cdot 1(27)\end{array}$ & $\begin{array}{l}\dagger \\
1.7(1) \\
1.9(4) \\
1.8(43)\end{array}$ \\
\hline
\end{tabular}

${ }^{*}$ No skin section with intact interfollicular epidermis available for analysis.

†No deaths during period.

gives the incidence and classification of cutaneous tumours. The highest incidence of cutaneous tumours was recorded in the group exposed to CAE; 41 of 48 animals $(85.4 \%)$ in this group had at least one cutaneous tumour. Furthermore, treatment with CAE induced the largest total number of cutaneous tumours, the largest number of animals with multiple cutaneous tumours, and the greatest number of animals with metastases of primary cutaneous tumours in drainage lymph nodes or lungs or both. By contrast, the groups exposed to HTAE 3 and HTAE 4 had the lowest incidence of cutaneous neoplasia-namely, six and seven of 48 animals $(12.5 \%$ and $14.6 \%)$ respectively. These groups also had the lowest total number of tumours, and in only one animal were metastases identified (after HTAE 3 treatment). The results recorded for groups exposed to HTAE 1 and HTAE 2 were intermediate between those for the CAE group and the HTAE 3 and HTAE 4 groups. No cutaneous tumours were recorded in the untreated controls or HTAE 5 group. Six mice of the positive controls (B-a-P) developed cutaneous tumours.
The results of statistical analysis of cutaneous tumour data are illustrated as a lifetable for $2 \mathrm{~mm}$ diameter tumours (fig).

\section{SYSTEMIC TUMOURS}

Table 5 gives the incidence of primary systemic $\dot{\omega}$ tumours. Tumours of lungs and lymphoreticular/ haematopoietic tissue were most frequently 을 identified, being recorded in all groups. The results $\vec{c}$ of statistical analysis are presented in table 6; there $\subseteq$ were no statistically significant differences in the $\vec{\nabla}$ incidence of systemic tumours in the treated groups compared with the untreated controls.

\section{NON-NEOPLASTIC PATHOLOGY}

Table 7 lists the incidence of major lesions. With the exception of HTAE 5, the incidence and severity of acute inflammatory lesions in the liver, stomach, and kidneys were increased in the treated groups compared with those in both the control groups; these $\overrightarrow{\overrightarrow{0}}$ lesions included hepatic microabscesses, focal 3 coagulative hepatic parenchymal necrosis, focal and $\supset$ diffuse gastritis, and suppurative nephritis. Hepatic

Table 4 Incidence and classification of cutaneous tumours of the treated site in CF1 mice after repeated topical application of $B$-a-P or one of six petroleum aromatic extracts for up to 78 weeks

\begin{tabular}{|c|c|c|c|c|c|c|c|c|}
\hline & \multicolumn{8}{|l|}{ Incidence } \\
\hline & Untreated & $B-a-P$ & $C A E$ & HTAE 1 & HTAE 2 & HTAE 3 & HTAE 4 & HTAE 5 \\
\hline Group size & 96 & 46 & 48 & 48 & 48 & 48 & 48 & 48 \\
\hline $\begin{array}{l}\text { Epidermis: } \\
\text { Papilloma } \\
\text { Squamous cell carcinoma } \\
\text { Basal cell carcinoma } \\
\text { Anaplastic carcinoma } \\
\text { Dermis: } \\
\text { Fibrosarcoma } \\
\text { Sloughed papillomas } \\
\text { Total No of cutaneous tumours } \\
\text { No of tumour bearing mice } \\
\text { No of mice with single cutaneous tumour } \\
\text { No of mice with multiple cutaneous } \\
\text { tumours } \\
\text { No of mice with metastasising } \\
\text { cutaneous tumours }\end{array}$ & & $\begin{array}{l}7 \\
6 \\
5 \\
1\end{array}$ & $\begin{array}{r}9 \\
176 \\
41 \\
7 \\
34 \\
15\end{array}$ & $\begin{array}{r}40 \\
8 \\
3 \\
1 \\
2 \\
54 \\
22 \\
8 \\
14 \\
2\end{array}$ & $\begin{array}{r}4 \\
47 \\
23 \\
11 \\
12 \\
\\
1\end{array}$ & $\begin{array}{l}7 \\
6 \\
5 \\
1 \\
1 \\
1\end{array}$ & $\begin{array}{l}4 \\
2 \\
1\end{array}$ & \\
\hline
\end{tabular}

Absence of a figure denotes no finding. 


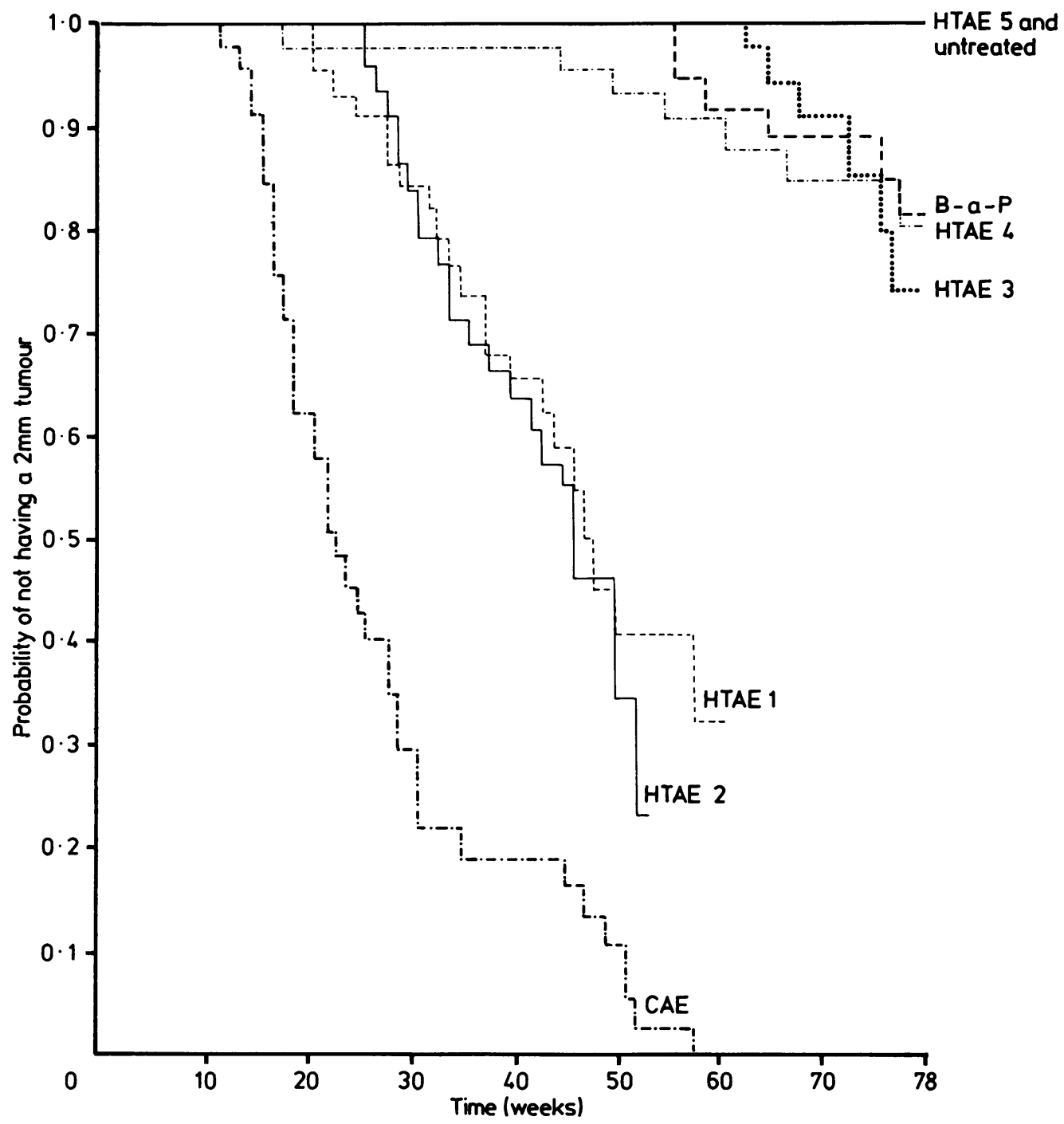

Fig Life table in respect of $2 \mathrm{~mm}$ cutaneous tumours.

amyloidosis was recorded in groups exposed to four of the hydrotreated aromatic extracts (HTAE 1-4).

Chronic non-suppurative nephritis was identified in $15 \%$ of the mice. This lesion was often associated with systemic hypertensive and degenerative vascular lesions, particularly arteritis of the ovarian and superior mesenteric vessels. Neither the incidence nor the severity of these lesions was increased by exposure to the aromatic extracts. Similarly, the incidence of hepatic single cell necrosis, focal hepatic parenchymal hyperplasia, and hydronephrosis was unaffected by treatment when compared with that in the untreated controls.

\section{Discussion}

This study was carried out to determine the carcinogenic potential of six petroleum aromatic extracts and to relate the findings to the PCA content of the extracts. The PCA content was determined by dimethyl sulphoxide extraction and expressed as a percentage of the total weight of the test substance.

From a feedstock with a PCA content of $17.2 \%$ $w / w$, three extracts with different PCA contents had been produced by pilot plant hydrotreatment and subsequent redistillation to remove light ends. These extracts, HTAE 1, HTAE 2, and HTAE 4 
Table 5 Classification and incidence of primary systemic tumours in CF1 female mice after topical application of B-a-P or one of $\mathrm{H}_{\mathrm{D}}$ petroleum aromatic extracts for up to 78 weeks




Table 7 Incidence of major non-neoplastic lesions in liver, stomach, and kidneys of CF1 female mice after topical application of $B-a-P$ or one of six petroleum aromatic extracts for up to 78 weeks

\begin{tabular}{|c|c|c|c|c|c|c|c|c|c|}
\hline & & \multicolumn{8}{|l|}{ Incidence } \\
\hline & & Untreated & $B-a-P$ & $C A E$ & HTAE 1 & $H T A E 2$ & HTAE 3 & HTAE 4 & HTAE 5 \\
\hline Group size & & 96 & 46 & 48 & 48 & 48 & 48 & 48 & 48 \\
\hline \multicolumn{10}{|l|}{$\begin{array}{l}\text { Incidence affected by treatment } \\
\text { Liver }\end{array}$} \\
\hline Microabscesses & $\begin{array}{l}\text { Few } \\
\text { Many }\end{array}$ & 2 & $\begin{array}{l}1 \\
2\end{array}$ & 2 & $\begin{array}{r}10 \\
; \quad 5\end{array}$ & $\begin{array}{r}11 \\
2\end{array}$ & $\begin{array}{l}3 \\
1\end{array}$ & 2 & \\
\hline $\begin{array}{l}\text { Focal coagulative necrosis } \\
\text { Amyloidosis } \\
\text { Stomach: }\end{array}$ & $\begin{array}{l}\text { Mild } \\
\text { Moderate } \\
\text { Severe }\end{array}$ & 7 & 2 & $\begin{array}{r}11 \\
5 \\
3\end{array}$ & $\begin{array}{l}4 \\
5 \\
3 \\
6\end{array}$ & $\begin{array}{l}\overline{4} \\
2 \\
1 \\
2\end{array}$ & $\begin{array}{r}10 \\
2 \\
3\end{array}$ & $\begin{array}{l}4 \\
2 \\
1 \\
2\end{array}$ & $\begin{array}{l}2 \\
1\end{array}$ \\
\hline Acute gastritis & $\begin{array}{l}\text { Mild } \\
\text { Moderate } \\
\text { Severe }\end{array}$ & & $\begin{array}{l}1 \\
2\end{array}$ & $\begin{array}{l}2 \\
1 \\
1\end{array}$ & $\begin{array}{l}3 \\
1\end{array}$ & $\begin{array}{l}2 \\
2 \\
1\end{array}$ & 1 & $\begin{array}{l}3 \\
1 \\
1\end{array}$ & 1 \\
\hline $\begin{array}{l}\text { Kidneys } \\
\text { Acute suppurative nephritis }\end{array}$ & $\begin{array}{l}\text { Mild } \\
\text { Moderate } \\
\text { Severe }\end{array}$ & 1 & 1 & 3 & $\begin{array}{l}2 \\
1\end{array}$ & $\begin{array}{l}1 \\
3\end{array}$ & $\begin{array}{l}2 \\
2\end{array}$ & 1 & 1 \\
\hline \multicolumn{10}{|c|}{$\begin{array}{l}\text { Incidence not affected by treatment } \\
\text { Liver }\end{array}$} \\
\hline $\begin{array}{l}\text { Single cell necrosis } \\
\text { Hyperplastic nodule(s) } \\
\text { Kidneys }\end{array}$ & & $\begin{array}{l}2 \\
6\end{array}$ & $\begin{array}{l}1 \\
2\end{array}$ & $\begin{array}{l}1 \\
1\end{array}$ & 2 & $\begin{array}{l}1 \\
2\end{array}$ & $\begin{array}{l}2 \\
2\end{array}$ & $\begin{array}{l}2 \\
4\end{array}$ & 3 \\
\hline $\begin{array}{l}\text { Chronic non-suppurative } \\
\text { nephritis } \\
\text { Hydronephrosis }\end{array}$ & $\begin{array}{l}\text { Mild } \\
\text { Moderate } \\
\text { Severe }\end{array}$ & $\begin{array}{r}8 \\
2 \\
11 \\
1\end{array}$ & $\begin{array}{l}7 \\
2 \\
6 \\
1\end{array}$ & 1 & $\begin{array}{l}2 \\
2\end{array}$ & & 6 & $\begin{array}{l}3 \\
4 \\
2 \\
1\end{array}$ & $\begin{array}{l}5 \\
1 \\
5 \\
1\end{array}$ \\
\hline
\end{tabular}

Absence of a figure denotes no finding.

had PCA contents of $9.2 \%, 8.7 \%$, and $6.0 \% \mathrm{w} / \mathrm{w}$ respectively. The experimental extract, HTAE 3 , had been hydrotreated in a refinery plant and was not dewaxed; the PCA content $(6.1 \% \mathrm{w} / \mathrm{w})$ was similar to that of the solvent dewaxed HTAE 4 . The experimental extract HTAE 5, with the lowest PCA content $(3.7 \% \mathrm{w} / \mathrm{w})$, was a solvent dewaxed hydrotreated residual oil from pilot plant production. These five products were tested for their potential to induce cutaneous and systemic neoplasia in female CF1 mice by application to the shorn dorsal skin for up to 78 weeks. The results were compared with those following application of a non-hydrotreated commercial aromatic extract (CAE) with a PCA content of $19.7 \% \mathrm{w} / \mathrm{w}$.

The major factors responsible for reduced survival were cutaneous ulceration or cutaneous neoplasia, or both, both lesions being related to treatment. The relative importance of the two lesions differed among the groups; cutaneous ulceration was the more important cause of premature morbidity in mice exposed to the four hydrotreated extracts HTAE 1-4, whereas cutaneous neoplasia was of greater significance in mice exposed to CAE.

Cutaneous neoplasia and ulceration adversely affected the health and survival of animals. Many of the neoplasms were large, ulcerated, and haemorrhagic; in a small number of mice, pulmonary metastases of cutaneous tumours were associated with clinical signs of respiratory distress. Cutaneous ulceration of the treated site or adjacent skin, often aggravated by scratching, was often associated with cachexia. Infection of and blood loss from areas of ulceration were major factors responsible for loss of weight and debility of affected mice. Multifocal acute inflammatory lesions in liver and kidneys were frequently associated with extensive cutaneous ulceration; septicaemia and toxaemia resulting from infection of the ulcers were major secondary factors contributing to premature mortality.

In control, HTAE 5, and B-a-P treated animals systemic neoplasia and inflammatory lesions, particularly chronic nephritis, were of relatively greater importance as causes of illness and mortality. These diseases represent natural causes of death of $\mathrm{CF} 1$ female mice in this laboratory and are primarily diseases of older animals. The higher percentage incidence in control, HTAE 5, and B-a-P decedents reflected the longer survival of animals in these groups compared with that in the other test groups.

The cutaneous carcinogenic potential of the extracts was assessed by both clinical observations and histological examination. A definitive clinical diagnosis of a cutaneous tumour was made when a nodule of $2 \mathrm{~mm}$ diameter persisted for two weeks. Use of these clinical criteria facilitated differentiation between small neoplastic lesions and focal inflammatory or hyperplastic lesions. Furthermore, 
since some cutaneous papillomas slough spontaneously, clinical data on the development of these tumours represented the only permanent record of their existence. The positive control compound (B-a-P, $12.5 \mu \mathrm{g} / \mathrm{ml}$ acetone) induced cutaneous tumours in $13 \%$ of treated animals, showing the susceptibility of female CF1 mice to a low dose of a known polycyclic aromatic carcinogen.

Five of the six aromatic extracts were cutaneous carcinogens for CF1 female mice. The commercial extract (CAE) had the highest carcinogenic potential, inducing the greatest number of tumours and with the shortest latent period; cutaneous tumours were induced in almost all animals of this group. This extract had a similar PCA content to that of the feedstock from which three of the hydrotreated products, HTAE 1, HTAE 2, and HTAE 4, were processed. After severe hydrotreatment, the carcinogenic potential of the extracts was reduced; HTAE 1 and HTAE 2, with PCA contents of $9 \cdot 2$ and $8.7 \% \mathrm{w} / \mathrm{w}$ respectively, were four times less likely to induce cutaneous tumours than CAE. The extracts HTAE 3 and HTAE 4, with lower PCA contents $(6.1$ and $6.0 \% \mathrm{w} / \mathrm{w})$, were relatively weak carcinogens and HTAE 5 with the lowest PCA content $(3.7 \% \mathrm{w} / \mathrm{w})$ was non-carcinogenic for murine skin. These results show that decreasing PCA content, as measured by dimethyl sulphoxide extraction, correlates with decreased cutaneous carcinogenic potential.

There was no evidence that exposure to the commercial or experimental hydrotreated extracts induced tumours at sites other than the treated

The results of this study show that severe hydro- $\vec{F}$ treatment reduces the carcinogenic potential of aromatic extracts of petroleum. Physicochemical $\frac{}{C}$ properties other than PCA content-for example, viscosity or the presence of cocarcinogens ${ }^{3}$-are likely to influence the biological activity of complex $\triangle$ products. Nevertheless, the PCA content of a pro- क duct, determined by dimethyl sulphoxide extraction, may be a useful indicator of carcinogenic potential.

\section{References}

' Cook JW, Hieger I, Kennaway EL, Mayneord WV. The production of cancer by pure hydrocarbons Part I. Proc R Soc (Lond) [Biol] 1932;111:455-84.

${ }^{2}$ Cook JW, Hewett CL. Isolation of a cancer producing hydrocarbon from coal tar part III. Journal of the Chemical Society 1933;398-405.

${ }^{3}$ Bingham E, Trosset RP, Warshawsky D. Carcinogenic potential of petroleum hydrocarbons. A critical review of the literature. J Environ Pathol Toxicol 1979;3:483-563.

${ }^{4}$ Institute of Petroleum. Polycyclic aromatics in petroleum fractions by dimethyl sulphoxide-refractive index method. In: IP standards for petroleum and its products. Part I Methods of $\vec{\varphi}$ analysis and testing. Vol 2. 40th annual ed. London: Institute of of Petroleum, 1981. (IP 346180.)

s Van Grondelle MC, Zeen PJ, van der Craats F. The combustion coulometric method for the determination of sulphur in gaseous and liquid products. Anal Chim Acta 1978;100:439-50.

- Peto R, Pike MC, Day NE, et al. Guidelines for simple, sensitive significance tests for carcinogenic effects in long-term animal experiments. WHO IARC Long-term and short-term screen- \& ing assays for carcinogens. A critical appraisal suppl 2 . 1980;311-426. 